\title{
Effect of changing photoperiod on peripheral plasma prolactin and progesterone concentrations in the tammar wallaby (Macropus eugenii)
}

\author{
L. A. Hinds and R. C. den Ottolander* \\ Division of Wildlife and Rangelands Research, CSIRO, P.O. Box 84, Lyneham, A.C.T. 2602, \\ Australia
}

\begin{abstract}
Summary. In tammar wallabies kept in normal daylengths between the equinoxes, births occurred at the normal time after the summer solstice and the progesterone profile reflected this cycle. There were no significant changes in plasma prolactin. In tammars placed in a $15 \mathrm{~L}: 9 \mathrm{D}$ photoperiod and then, 5 weeks later, in $12 \mathrm{~L}: 12 \mathrm{D}$, births occurred 29-36 days after the daylength was reduced. A characteristic transient peak of plasma progesterone occurred 8-14 days after the change, indicating a delay of 3-9 days in the resumption of luteal activity. Plasma prolactin levels were significantly higher $(>40 \mathrm{ng} / \mathrm{ml})(P<0 \cdot 01)$ during the solstitial daylength, declining to $<30 \mathrm{ng} / \mathrm{ml}$ within 14 days of the reduction in photoperiod. Animals kept in $12 \mathrm{~L}: 12 \mathrm{D}$ and then in 9L:15D gave birth asynchronously after entry into the pens, suggesting that this daylength (12L:12D) is permissive. Changes in plasma progesterone reflected the resumption of luteal activity but no significant changes in plasma prolactin were observed.

This study shows that the inhibition of the corpus luteum in seasonal quiescence can be maintained in the presence or absence of elevated prolactin levels, indicating that other factors, perhaps of pineal origin, may also be involved.
\end{abstract}

\section{Introduction}

Seasonal breeding, closely associated with annual changes in photoperiod, is a common phenomenon in eutherian mammals (Reiter, 1980). Many marsupials also breed at specific times of the year but in only 3 species has the influence of changing photoperiod on breeding activity been examined. Manipulation of photoperiod induced an earlier return to breeding in the dasyurid, Sminthopsis crassicaudata (Godfrey, 1969), and allowed breeding to continue after the end of the normal breeding season in the American opossum, Didelphis virginiana (Farris, 1957). Animals of both of these species begin breeding after the winter solstice in response to increasing daylength. In the tammar wallaby, Macropus eugenii, births occur in the majority of females about 1 month after the summer solstice (Andrewartha \& Barker, 1969). This seasonality is retained in tammars transferred to the northern hemisphere as they again give birth 1 month after the summer solstice, in June (Berger, 1970).

Conception occurs immediately post partum and the resulting corpus luteum and blastocyst remain quiescent for 11 months (Berger, 1966). Removal of the pouch young (RPY) during the period of declining daylength (lactational quiescence) induces reactivation of the corpus luteum and blastocyst; a peak of plasma progesterone occurs on Day $5.6 \pm 0.55$ (mean \pm s.d.) after RPY

* Present address: Wijngaardlaan 47, 2252 XK Voorschoten, The Netherlands. 
(Hinds \& Tyndale-Biscoe, 1982a) and birth on Day 26.4 \pm 0.57 after RPY (Merchant, 1979). Reactivation in response to loss or removal of the pouch young does not occur during the period of increasing daylength but can be induced by altering the photoperiod. Sadleir \& Tyndale-Biscoe (1977) demonstrated that a reduction in daylength by $3 \mathrm{~h}$ during the non-breeding season (seasonal quiescence) could induce reactivation of the corpus luteum and blastocyst such that birth and postpartum oestrus occurred 29-36 days later. This represents a lengthening of the normal cycle by 3-10 days.

Prolactin is thought to be the agent which tonically inhibits the corpus luteum during quiescence (Tyndale-Biscoe \& Hawkins, 1977; Sernia \& Tyndale-Biscoe, 1979; Stewart \& TyndaleBiscoe, 1982), and plasma prolactin concentrations, which are low during the period of declining daylength but high during the period of increasing daylength (Tyndale-Biscoe \& Hinds, 1981, 1983), support this. The aims of the present study were two-fold. Firstly, to examine the hypothesis that seasonal changes in plasma prolactin are directly related to changing photoperiod, plasma prolactin concentrations were measured before and after an artificial change in photoperiod. Secondly, to determine whether, and when, the transient peak of plasma progesterone occurs after early termination of diapause induced by a reduction in photoperiod, plasma progesterone concentrations were measured before and after a change in photoperiod.

\section{Materials and Methods}

Animals. Animals were maintained in the 6 light-proof pens described by Sadleir \& Tyndale-Biscoe (1977). Three non-lactating females whose young had been removed at least 5 weeks earlier were placed in each pen and provided with lucerne chaff, oats, fresh cabbage and water ad libitum. The experiment began on 11 September 1980, using 3 light regimens in duplicate (Text-fig. 1). Animals in Group A (controls kept in normal Canberra daylength) $(\mathrm{N}=6)$ were subjected to a changing photoperiod which followed the pattern for $37.5^{\circ} \mathrm{S}$ latitude; those in Group B (solstitial photoperiod) $(\mathrm{N}=6)$ were subjected to $15 \mathrm{~h}$ light/day (15L:9D) until 20 October 1980 , when the daylength was reduced to $12 \mathrm{~L}: 12 \mathrm{D}$; and tammars in Group $\mathrm{C}$ (equinoctial photoperiod) $(\mathrm{N}=6)$ were kept in $12 \mathrm{~L}: 12 \mathrm{D}$ until 20 October 1980, when the daylength was reduced to $9 \mathrm{~L}: 15 \mathrm{D}$.

Blood samples $(3.5 \mathrm{ml})$ were collected from the lateral tail vein of each animal at weekly intervals from 15 September until the completion of the experiment. Daily blood samples were collected for 15 days after the change of lighting regimen on 20 October, and during this period the red blood cells were resuspended in sterile, buffered sodium citrate and returned to the vascular system to maintain normal haematocrit levels. All blood samples were taken between $08: 30$ and $10: 30 \mathrm{~h}$, centrifuged, and the plasma stored in 2 aliquots at $-20^{\circ} \mathrm{C}$ until assayed for progesterone and prolactin respectively. One male was placed in each pen on 7 October 1980 . This was necessary since the endpoint of the experiment was the detection of births or, for any female not carrying a dormant blastocyst, detection of oestrus. Oestrus was detected by the presence of a copulatory plug in the urogenital sinus.

Assays. Plasma progesterone was determined by radioimmunoassay as described by Sernia, Hinds \& Tyndale-Biscoe (1980) using antiserum S230. The assay had a sensitivity of $25 \mathrm{pg} / \mathrm{ml}$ plasma and the intra- and inter-assay coefficients of variation were 9 and $13 \%$ respectively. Prolactin was determined by the heterologous radioimmunoassay of McNeilly \& Friesen (1978) validated for the tammar by Hinds \& Tyndale-Biscoe (1982b) using antibody 33-9 and ovine prolactin NIH-P-S12 as standard. The limit of sensitivity was $3 \mathrm{ng} / \mathrm{ml}$. Intra- and inter-assay coefficients of variation were 8 and $12 \%$ respectively. The recovery of a range of concentrations of prolactin added to tammar plasma closely correlated with the actual amount added $(r=0.998, P<$ 0.001 ) and was always within $12 \%$ of the expected value. All samples for an individual animal were analysed within one assay. 

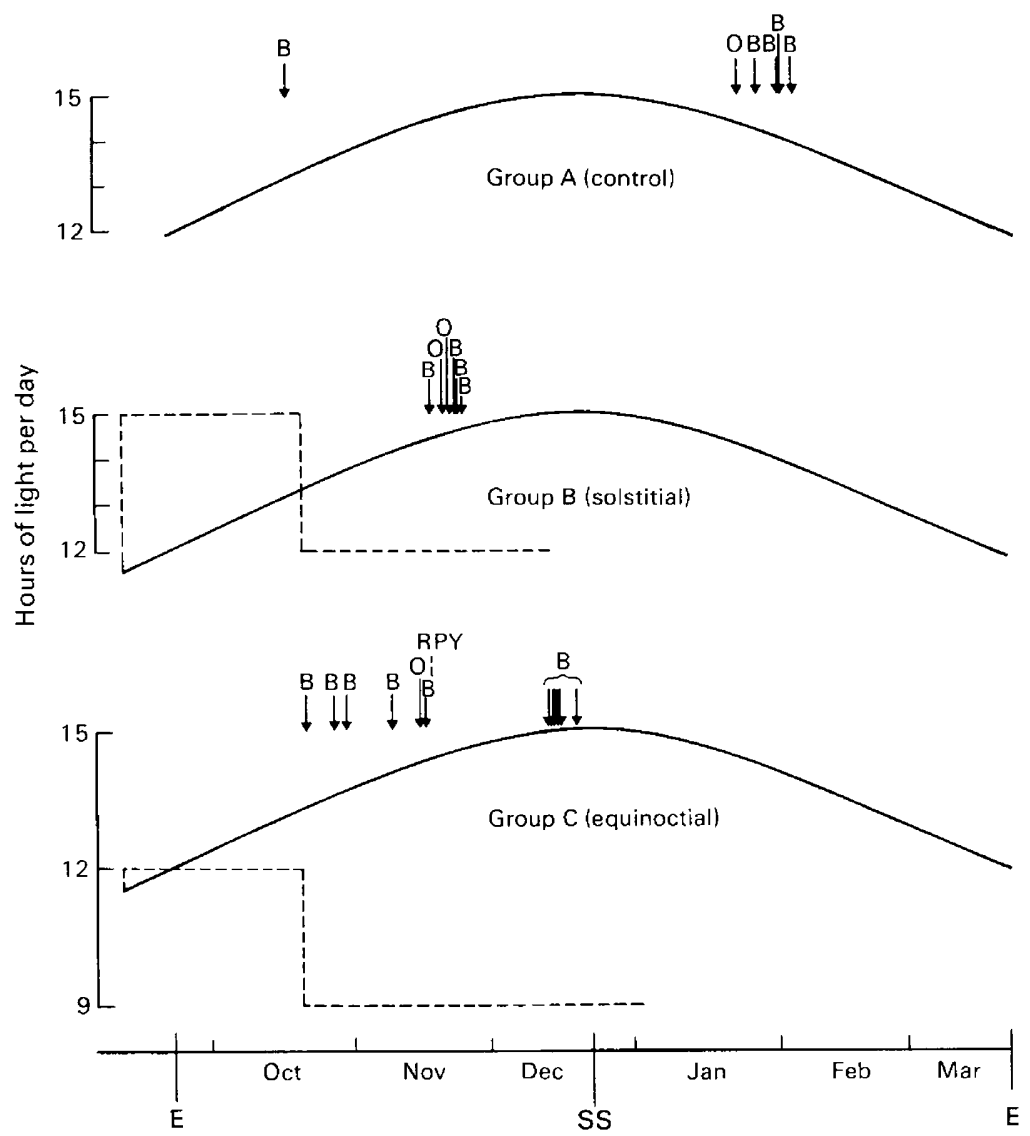

Text-fig. 1. Summary of the experimental design and the results. The solid lines represent natural light at $37.5^{\circ} \mathrm{S}$. Broken lines represent artificial light in light proof pens. Arrows indicate time of birth (B) and oestrus (O) of individual animals. RPY = removal of pouch young, $\mathrm{E}=$ equinox, $\mathrm{SS}=$ summer solstice.

\section{Results}

\section{Group $A$}

One female which gave birth 36 days after being placed in the pen was removed from the experiment, and is therefore not included in the analyses of the hormones. The other 5 females gave birth and/or mated between 23 January and 4 February $1981,134-146$ days $(140 \cdot 8 \pm 2 \cdot 1$, mean \pm s.e.m.) after the start of the experiment. The mean date of birth/oestrus for these 5 animals was 29 January, the same as for animals in the outside yards.

\section{Group $B$}

None of these animals gave birth or mated during the period they were exposed to long photoperiod but all 6 gave birth and/or mated 29-36 days after the photoperiod was reduced to 12L :12D (Table 1). This response is identical to that described by Sadleir \& Tyndale-Biscoe (1977) for this treatment. 


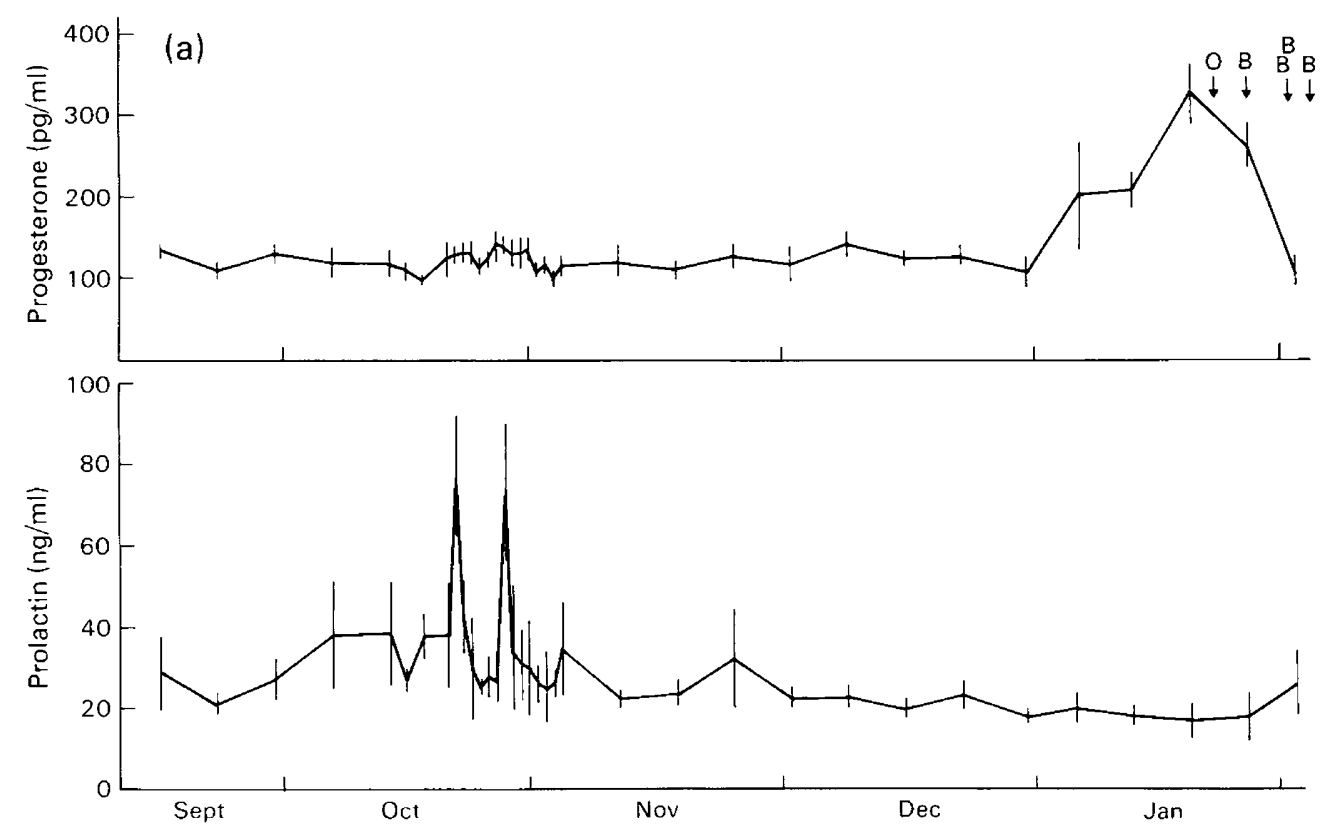

Text-fig. 2. Mean \pm s.e.m. plasma hormone patterns for 5 tammars (a) in Group A (controls) during the experimental period; (b) for 6 tammars in Group B (solstitial daylength); and (c) for 6 animals in Group C (equinoctial daylength). Arrows indicate time of birth (B) and oestrus (O). RPY = removal of pouch young. Broken vertical line indicates when daylength was reduced from 15L:9D to $12 \mathrm{~L}: 12 \mathrm{D}$ for Group B and from $12 \mathrm{~L}: 12 \mathrm{D}$ to $9 \mathrm{~L}: 15 \mathrm{D}$ for Group C.

\section{Group C}

The animals responded to the initial change from outside natural lighting to a $12 \mathrm{~L}: 12 \mathrm{D}$ photoperiod, i.e. before the daylength was reduced to $9 \mathrm{~L}: 15 \mathrm{D}$. The response was asynchronous and births and/or oestrus occurred at random intervals between 40 and 66 days after the start of the experiment (Table 2). Nevertheless, when the pouch young were removed from these females on 17 November all gave birth and/or entered oestrus $28.2 \pm 0.8$ days later (Table 2 ). These cycles were similar in length to cycles initiated by removal of pouch young in the breeding season (Merchant, 1979).

\section{Plasma progesterone concentrations}

In all groups resumption of luteal development was reflected by an increase in plasma progesterone levels. In Group A plasma progesterone remained low $(<200 \mathrm{pg} / \mathrm{ml})$ until early January when reactivation of the corpus luteum occurred. Levels then increased $2-3$-fold to reach a maximum $(>300 \mathrm{pg} / \mathrm{ml}$ ) before parturition, after which there was a decline to basal concentrations (Text-fig. 2a). This profile is very similar to that described by Tyndale-Biscoe $\&$ Hinds (1981) for animals undergoing natural reactivation of the corpus luteum and blastocyst, after the summer solstice, in outside pens. In Group B clearly defined peaks of progesterone, associated with the early stages of reactivation of the corpus luteum, occurred 8-14 days after the reduction in daylength in 5 of the 6 females (Table 1; Text-fig. 2b), while the interval from the peak to birth was $23.0 \pm 0.7$ (mean \pm s.e.m.) days (Table 1 ). In Group $C$, in the cycle initiated by removal of pouch young, transient peaks of progesterone were observed on Day 6.0 \pm 0.3 (mean \pm s.e.m.) after RPY (Text- 

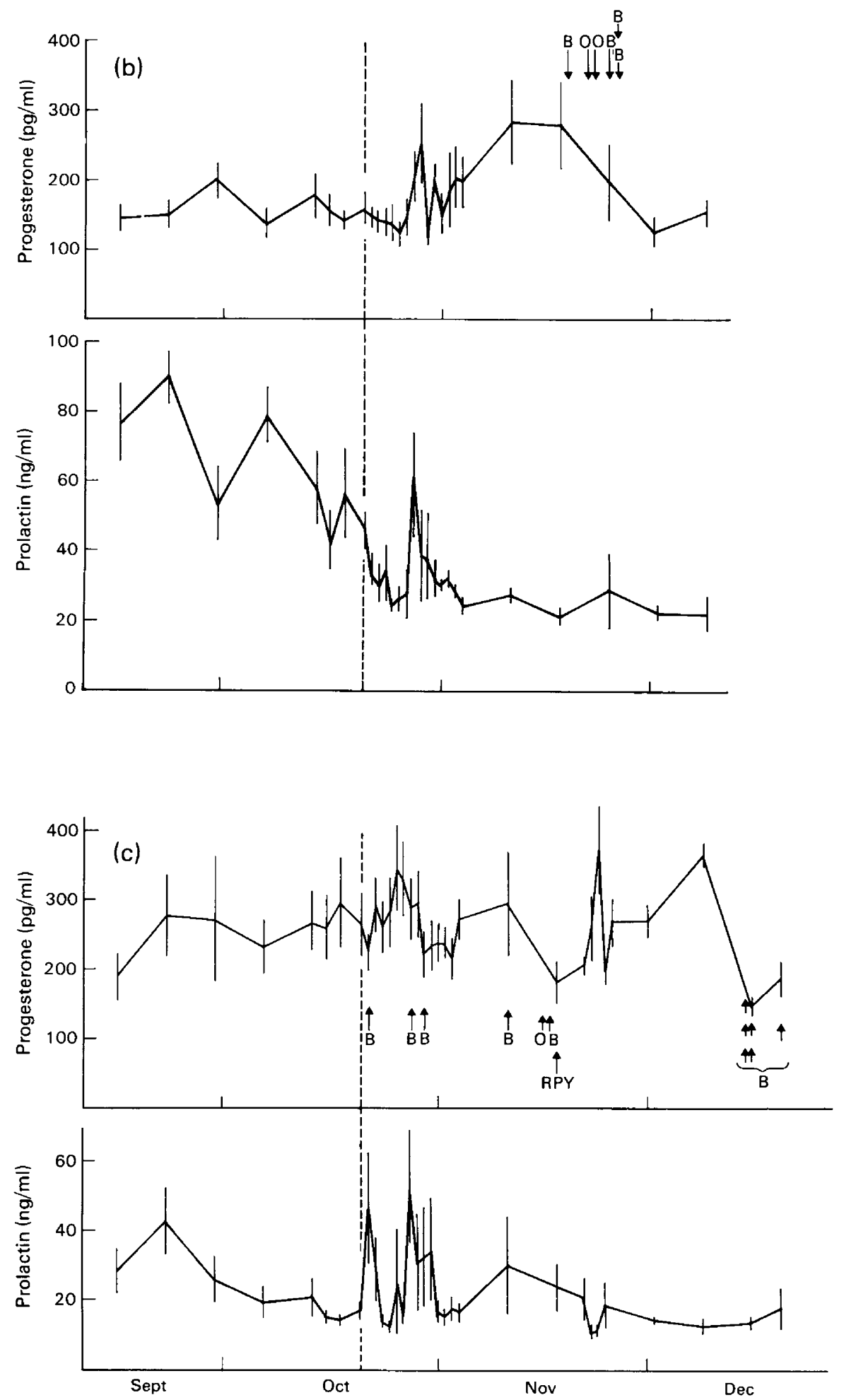

Text-fig. 2 (cont.) 
Table 1. Intervals from pen entry to birth and/or oestrus; from the change in photoperiod to birth/oestrus and to the transient peak of progesterone; and from the peak of progesterone to birth/oestrus for animals in Group B (solstitial daylength)

\begin{tabular}{|c|c|c|c|c|}
\hline \multirow[b]{2}{*}{$\begin{array}{l}\text { Animal } \\
\text { no. }\end{array}$} & \multirow{2}{*}{$\begin{array}{l}\text { Days from } \\
\text { pen entry } \\
\text { to birth/ } \\
\text { oestrus }\end{array}$} & \multicolumn{2}{|c|}{$\begin{array}{l}\text { Days from change } \\
\text { of photoperiod }\end{array}$} & \multirow{2}{*}{$\begin{array}{l}\text { Days from } \\
\text { progesterone peak } \\
\text { to birth or oestrus }\end{array}$} \\
\hline & & To birth/oestrus & $\begin{array}{c}\text { To transient } \\
\text { progesterone peak }\end{array}$ & \\
\hline 4506 & 75 & 36 & 14 & 22 \\
\hline 4508 & 74 & 35 & 12 & 23 \\
\hline 4700 & 75 & 36 & - & - \\
\hline 4403 & 68 & 29 & 8 & 21 \\
\hline 4465 & 72 & 33 & 8 & 25 \\
\hline 4904 & 71 & 32 & 8 & 24 \\
\hline Mean \pm s.e.m. & $72 \cdot 5 \pm 1 \cdot 1$ & $33 \cdot 5 \pm 1 \cdot 1$ & $10 \pm 1 \cdot 3$ & $23 \cdot 0 \pm 0 \cdot 7$ \\
\hline
\end{tabular}

Table 2. Intervals from entry into experimental pens, change of photoperiod, and removal of pouch young (RPY) to birth/oestrus; from RPY to the peak of progesterone and from the peak of progesterone to birth/oestrus for animals in Group C (equinoctial daylength)

\begin{tabular}{lccccc}
\hline $\begin{array}{c}\text { Animal } \\
\text { no. }\end{array}$ & $\begin{array}{c}\text { Days from pen } \\
\text { entry to } \\
\text { birth/oestrus }\end{array}$ & $\begin{array}{c}\text { Days from change } \\
\text { in photoperiod to } \\
\text { birth/oestrus }\end{array}$ & $\begin{array}{c}\text { Days from RPY } \\
\text { to second } \\
\text { birth/oestrus }\end{array}$ & $\begin{array}{c}\text { Days from } \\
\text { RPY to } \\
\text { peak of } \\
\text { progesterone }\end{array}$ & $\begin{array}{c}\text { Days from } \\
\text { progesterone } \\
\text { peak to } \\
\text { birth/oestrus }\end{array}$ \\
\hline 4670 & 66 & 27 & 32 & -7 & -1 \\
4867 & 46 & 7 & 28 & 6 & 22 \\
4941 & 65 & 26 & 28 & 7 & 21 \\
4410 & 40 & 1 & 27 & 6 & 21 \\
4437 & 60 & 21 & 27 & 6 & 21 \\
4546 & 48 & 9 & 27 & $6 \pm 0 \cdot 3$ & $21 \cdot 4 \pm 0 \cdot 3$ \\
Mean \pm s.e.m. & $54 \cdot 2 \pm 4 \cdot 5$ & $15 \cdot 2 \pm 4 \cdot 5$ & $28 \cdot 2 \pm 0 \cdot 8$ & &
\end{tabular}

fig. 2c) while the interval from the peak to birth was $21 \cdot 4 \pm 0 \cdot 2$ (mean \pm s.e.m.) days (Table 2). In both groups plasma progesterone levels in the later stages of the cycle followed the same pattern as described for animals in Group A.

\section{Plasma prolactin concentrations}

In Group A there were no significant changes in plasma prolactin levels during the experiment. Concentrations remained low $(<40 \mathrm{ng} / \mathrm{ml})$ throughout except during the period of daily blood sampling when much higher levels (>80 ng/ml) were recorded on some days (Text-fig. 2a). This response occurred in all treatment groups and coincided with the period when red blood cells were being returned to the circulation. In Group B prolactin levels in all females were high $(>40 \mathrm{ng} / \mathrm{ml})$ when the daylength was $15 \mathrm{~L}: 9 \mathrm{D}$, but declined to basal levels $(<30 \mathrm{ng} / \mathrm{ml})$ within 14 days of the reduction of daylength to $12 \mathrm{~L}: 12 \mathrm{D}$ (Text-fig. $2 \mathrm{~b}$ ). It was during this 14-day interval that the corpus luteum was reactivated as indicated by the transient peak of progesterone. Within treatment analysis of variance showed that the prolactin levels during $15 \mathrm{~L}: 9 \mathrm{D}$ photoperiod were significantly higher $(P<0.01)$ than concentrations during 12L:12D daylength, while between-treatment comparisons revealed that concentrations during 15L:9D photoperiod were significantly higher ( $P$ $<0.01$, analysis of variance) than levels in Group A animals at this time. In Group C mean plasma 
prolactin levels were similar to those observed for Group A animals. There was no marked decline in levels when the daylength was reduced by $3 \mathrm{~h}$ as observed for Group B animals (Text-fig. 2c). In 3 animals which gave birth between 20 and 29 October there was a peak of prolactin coincident with parturition. This surge of prolactin at parturition has recently been described (Hinds \& TyndaleBiscoe, 1982b; Tyndale-Biscoe, Hinds, Horn \& Jenkin, 1983), and accounts for some of the large variation in prolactin levels during this period of daily sampling.

\section{Discussion}

The present study has confirmed the finding of Sadleir \& Tyndale-Biscoe (1977) that early termination of diapause in the female tammar occurs in a highly synchronized manner in response to reduced photoperiod. However, all females exposed to a constant daylength of $12 \mathrm{~L}: 12 \mathrm{D}$ also resumed breeding although at apparently random intervals after entry into the experimental pens. This response, also observed by Sadleir \& Tyndale-Biscoe (1977) for 3 of 7 females, suggests that equinoctial daylength is permissive of reproductive activity so that, as in lactational quiescence, removal of pouch young resulted in immediate reactivation of the corpus luteum. The same response to removal of pouch young was observed in seasonal quiescence by Renfree, Lincoln, Almeida \& Short (1981) for female tammars deprived of the superior cervical sympathetic ganglia in lactational quiescence.

Sadleir \& Tyndale-Biscoe (1977) also reported that their control group gave birth 1 month earlier than expected, and suggested that the experimental conditions were not fully equivalent to the natural environment. However, in the present study the animals in the control group gave birth or became oestrous at the expected time in late January or early February. The dates of birth and estimated times of reactivation were not significantly different from those recorded for animals in outside pens in Canberra or for animals on Kangaroo Island (Renfree \& Tyndale-Biscoe, 1973). We are unable to explain this result as there were no apparent differences in the experimental conditions used by Sadleir \& Tyndale-Biscoe (1977) and us.

The endocrine changes associated with the photoperiod-induced responses were well defined, particularly with respect to plasma progesterone concentrations. The increase in plasma progesterone values clearly reflected reactivation of the corpus luteum and is very similar to the response observed by Tyndale-Biscoe \& Hinds $(1981,1983)$ during the period of natural reactivation of the corpus luteum around the summer solstice. In eutherians exhibiting embryonic diapause, including the spotted skunk (Mead \& Eik-Nes, 1969), badger (Bonnin, Canivenc \& Ribes, 1978) and mink (Møller, 1973; Allais \& Martinet, 1978), the termination of diapause is associated with secretion of progesterone by the newly active corpus luteum. Moreover, for mink subjected to a 14L:10D photoperiod (Allais \& Martinet, 1978) and for badgers placed in an artificial winter photoperiod (Canivenc \& Bonnin, 1979), the period of diapause was shortened and, after the change in photoperiod, plasma progesterone levels were similar to those observed at the normal time of implantation and during pregnancy. Similar correlations can be made with the progesterone concentrations found in this study of the tammar, particularly with respect to the transient peak of progesterone described by Hinds \& Tyndale-Biscoe (1982a). In the breeding season this peak occurs $5.6 \pm 0.35$ (mean \pm s.e.m.) days after removal of pouch young; in the present study it occurred at this time in Group $\mathrm{C}$ but 8-14 days after the change in photoperiod in Group B. Nevertheless, the interval from the peak to birth was the same as in the normal delayed cycle, which indicates that there was a delay in the response of the corpus luteum of 3-9 days after the change in daylength when compared to the interval after the removal of pouch young.

The response of plasma prolactin concentrations to photoperiod change is not so well defined. Many seasonally breeding eutherian species, including sheep (Walton, McNeilly, McNeilly \& Cunningham, 1977), cattle (Koprowski \& Tucker, 1973), rhesus monkeys (Beck \& Wuttke, 1979), goats (Buttle, 1974), white-tailed deer (Mirarchi, Howland, Scanlon, Kirkpatrick \& Sanford, 1978) 
and the golden hamster (Bex, Bartke, Goldman \& Dalterio, 1978) exhibit circannual and/or circadian variations in plasma prolactin and some studies strongly suggest that there is a close relationship between seasonal changes in photoperiod, prolactin levels and breeding activity (Walton et al., 1977). Tyndale-Biscoe \& Hinds $(1981,1983)$ observed seasonal changes in prolactin levels in non-lactating tammars; higher levels $(>40 \mathrm{ng} / \mathrm{ml})$ occurred in the second half of the year during seasonal quiescence when the daylength was increasing, and basal levels before the onset of reactivation of the corpus luteum after the summer solstice. In the present study, animals placed in a long daylength (15L:9D) had high prolactin values which subsequently decreased to basal concentrations when the daylength was reduced to $12 \mathrm{~L}: 12 \mathrm{D}$. Since the blastocysts and corpora lutea of these females were reactivated during this period of declining prolactin concentrations, a close correlation between high prolactin values and non-breeding is suggested. These findings are consistent with the hypothesis of Tyndale-Biscoe \& Hawkins (1977) that prolactin is the major factor causing inhibition of corpus luteum activity during quiescence. They found that injection of prolactin after removal of pouch young in lactational quiescence or after hypophysectomy in seasonal quiescence could delay reactivation of the corpus luteum for the duration of the treatment. Subsequent measurement of plasma prolactin levels demonstrated that there was a seasonal change in plasma prolactin concentrations (Tyndale-Biscoe \& Hinds 1981) which supported the hypothesis and indicated that changes in the levels of prolactin could be important for the maintenance and termination of diapause. However, in the present study the low and unchanging levels of prolactin in Groups $\mathrm{A}$ and $\mathrm{C}$ indicate that quiescence and reactivation do not depend solely on changes in circulating prolactin levels. This result is not unlike the response of the tammar to bromocriptine at, and after, the summer solstice when plasma prolactin levels were consistently low; injection of bromocriptine at the summer solstice did not induce reactivation of the corpus luteum but, 2 months later, in the same group of animals it did (Tyndale-Biscoe \& Hinds, 1983).

The results of this study therefore support the conclusion of Tyndale-Biscoe \& Hinds (1983) that, in addition to prolactin, other factors, perhaps of pineal origin, may also be involved in the inhibition of the corpus luteum.

We thank Dr Alan McNeilly and Dr Ron Cox for donations of antiserum; Roy Coles and Ray Leckie for help in collection of blood samples; Dr C. H. Tyndale-Biscoe, Division of Wildlife and Rangelands Research, CSIRO, Canberra, and Dr P. A. Janssens, Zoology Department, ANU, for helpful criticism of the project; and Ms S. M. Carpenter, Division of Mathematics \& Statistics, CSIRO, Canberra for advice and assistance with the statistical analyses.

\section{References}

Allais, C. \& Martinet, L. (1978) Relation between daylight ratio, plasma progesterone levels and timing of nidation in mink (Mustela vison). J. Reprod. Fert. 54, 133-136.

Andrewartha, H.G. \& Barker, S. (1969) Introduction to a study of the ecology of the Kangaroo Island wallaby, Protemnodon eugenii (Desmarest) within Flinders Chase, Kangaroo Island, South Australia. Trans. Roy. Soc. S. Aust. 93, 127-132.

Beck, W. \& Wuttke, W. (1979) Annual rhythms of luteinizing hormone, follicle-stimulating hormone, prolactin and testosterone in the serum of male rhesus monkeys. J. Endocr. 83, 131-139.

Berger, P.J. (1966) Eleven-month 'embryonic diapause' in a marsupial. Nature, Lond. 211, 435436.

Berger, P.J. (1970) The reproductive biology of the tammar wallaby Macropus eugenii (Desmarest). Ph.D. thesis, Tulane University.
Bex, F., Bartke, A., Goldman, B.D. \& Dalterio, S. (1978) Prolactin, growth hormone, luteinizing hormone receptors, and seasonal changes in testicular activity in the golden hamster. Endocrinology 103, 2069-2080.

Bonnin, M., Canivenc, R. \& Ribes, C.L. (1978) Plasma progesterone levels during delayed implantation in the European badger (Meles meles). J. Reprod. Fert. 52, 55-58.

Buttle, H.L. (1974) Seasonal variation of prolactin in plasma of male goats. J. Reprod. Fert. 37, 95-99.

Canivenc, R. \& Bonnin, M. (1979) Delayed implantation is under environmental control in the badger (Meles meles L.). Nature, Lond. 278, 849-850.

Farris, E.J. (1957) The Care and Breeding of Laboratory Animals, p. 256. John Wiley, New York.

Godfrey, G.K. (1969) Reproduction in a laboratory colony of the marsupial mouse Sminthopsis larapinta (Marsupialia: Dasyuridae). Aust. J. Zool. 17, 637654. 
Hinds, L.A. \& Tyndale-Biscoe, C.H. (1982a) Plasma progesterone levels in the pregnant and non-pregnant tammar, Macropus eugenii. J. Endocr. 93, 99-107.

Hinds, L.A. \& Tyndale-Biscoe, C.H. (1982b) Prolactin in the marsupial Macropus eugenii, during the estrous cycle, pregnancy and lactation. Biol. Reprod. 26, 391398.

Koprowski, J.A. \& Tucker, H.A. (1973) Serum prolactin during various physiological states and its relationship to milk production in the bovine. Endocrinology 92, 1480-1487.

McNeilly, A.S. \& Friesen, H.G. (1978) Heterologous radioimmunoassay for rabbit prolactin. Endocrinology 102, 1539-1547.

Mead, R.A. \& Eik-Nes, K.B. (1969) Seasonal variation in plasma levels of progesterone in western forms of the spotted skunk. J. Reprod. Fert., Suppl. 6, 397-403.

Merchant, J.C. (1979) The effect of pregnancy on the interval between one oestrus and the next in the tammar wallaby, Macropus eugenii. J. Reprod. Fert. 56, 459-463.

Mirarchi, R.E., Howland, B.E., Scanlon, P.F., Kirkpatrick, R.L. \& Sanford, L.M. (1978) Seasonal variation in plasma LH, FSH, prolactin, and testosterone concentrations in adult male white-tailed deer. Can. J. Zool. 56, 121-127.

Meller, O.M. (1973) The progesterone concentrations in the peripheral plasma of the mink (Mustela vison) during pregnancy. $J$. Endocr. 56, 121-132.

Reiter, R.J. (1980) Seasonal reproduction: an expedient and essential artifice. Prog. Reprod. Biol. 5, 1-4.

Renfree, M.B. \& Tyndale-Biscoe, C.H. (1973) Intrauterine development after diapause in the marsupial Macropus eugenii. Devl Biol. 32, 28-40.

Renfree, M.B., Lincoln, D.W., Almeida, O.F.X. \& Short, R.V. (1981) Abolition of seasonal embryonic diapause in a wallaby by pineal denervation. Nature, Lond. 293, 138-139.

Sadleir, R.M.F.S. \& Tyndale-Biscoe, C.H. (1977) Photoperiod and the termination of embryonic diapause in the marsupial Macropus eugenii. Biol. Reprod. 16, 605-608.

Sernia, C. \& Tyndale-Biscoe, C.H. (1979) Prolactin receptors in the mammary gland, corpus luteum and other tissues of the tammar wallaby, Macropus eugenii. J. Endocr. 83, 79-89.

Sernia, C., Hinds, L. \& Tyndale-Biscoe, C.H. (1980) Progesterone metabolism during embryonic diapause in the tammar wallaby, Macropus eugenii. J. Reprod. Fert. 60, 139-147.

Stewart, F. \& Tyndale-Biscoe, C.H. (1982) Prolactin and luteinizing hormone receptors in marsupial corpora lutea: relationship to control of luteal function. $J$. Endocr. 92, 63-72.

Tyndale-Biscoe, C.H. \& Hawkins, J. (1977) The corpora lutea of marsupials: aspects of function and control. In Reproduction and Evolution, pp. 245-252. Eds J. H. Calaby \& C. H. Tyndale-Biscoe. Australian Academy of Science, Canberra.

Tyndale-Biscoe, C.H. \& Hinds, L. (1981) Hormonal control of the corpus luteum and embryonic diapause in macropodid marsupials. J. Reprod. Fert., Suppl. 29, 111-117.

Tyndale-Biscoe, C.H. \& Hinds, L.A. (1983) Seasonal patterns of circulating progesterone and prolactin and response to bromocriptine in the female tammar Macropus eugenii. Gen. comp. Endocr. (in press).

Tyndale-Biscoe, C.H., Hinds, L.A., Horn, C.A. \& Jenkin, G. (1983) Hormonal changes at oestrus, parturition and post-partum oestrus in the tammar wallaby (Macropus eugenii). J. Endocr. 96, 155-161.

Walton, J.S., McNeilly, J.R., McNeilly, A.S. \& Cunningham, F.J. (1977) Changes in concentrations of follicle-stimulating hormone, luteinizing hormone, prolactin and progesterone in the plasma of ewes during the transition from anoestrus to breeding activity. $J$. Endocr. 75, 127-136.

Received 15 March 1983 